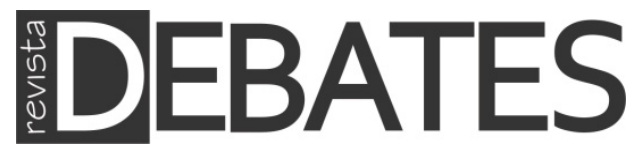

\title{
Lens distortion: image capture, racism and subversion from colonial photography to the iborder
}

\author{
Distorção de lentes: captura de imagem, racismo e subversão da \\ fotografia colonial à "iborder"
}

\section{Lorenzo Rinelli}

\begin{abstract}
This intervention emerged from the increase of use of facial recognition technologies on population management, specifically on European migration control. Inspired by these circumstances I reflect over the use of optical lens from the early use of the camera by Europeans as colonial weapon in connection to present-day image capture devices as a tracking tool to detect and encamp people on the move. I believe that this archaeological methodology with an aesthetic sensibility allows me to reveal how contemporary disciplinary techniques of image capture are produced by a complex relation of power and knowledge framed within the same biometric logic of truth-seeking that marked the European colonial domination. I conclude my intervention by featuring a powerful artwork of a contemporary artist which disrupts the illusory claim of scientific truth and impartiality that still colonizes the system of visual verification and by evoking forgotten African roots of modernity, ultimately upset its cluster of relations of power.
\end{abstract}

\section{Keywords}

Aesthetics of Politics; Facial Recognition; Migration Studies; Coloniality; Rujunko Pugh.

\section{Resumo}

Esta intervenção surgiu do aumento da utilização de tecnologias de reconhecimento facial na gestão da população, mais especificamente no controle da migração europeia. Inspirado por essas circunstâncias, reflito sobre o uso de lentes ópticas desde o início do uso da câmera pelos europeus como arma colonial até os dispositivos de captura de imagens atuais como uma ferramenta de rastreamento para detectar e acampar pessoas em movimento. Creio que esta metodologia arqueológica com sensibilidade estética permite revelar como as técnicas disciplinares contemporâneas de captação de imagens são produzidas por uma relação complexa de poder e saber enquadrada na mesma lógica biométrica de procura da verdade que marcou a dominação colonial europeia. Concluo minha intervenção apresentando uma poderosa obra de arte de uma artista contemporânea que rompe a reivindicação ilusória de verdade científica e imparcialidade que ainda coloniza o sistema de verificação visual e evocando raízes africanas esquecidas da modernidade, em última instância perturbando seu conjunto de relaçóes de poder.

\section{Palavras-chave}

Estética da Política; Reconhecimento Facial; Estudos de Migração; Colonialidade; Rujunko Pugh. 


\section{Introduction}

A new notion of the world and "idea of order" was being map now no longer upon physical cosmos [...] Instead, the projected space of Otherness" was now to be mapped on phenotypical and religio-cultural differences between human variation and/or population groups, while the new idea of order was now to be defined in terms of degrees of rational perfection/imperfection, as degrees ostensibly ordained by the GrecoChristian cultural construct deployed by Sepulveda as that the law of nature.

(WYNTER, 2003, p. 269)

The concept of natural law mentioned by Sylvia Wynter was instrumental to order different human beings in distinct groups, to classify them similarly to the newly discovered laws of nature that regulate the processes of functioning of Earth's biodiversity. The evident physical differences, visible to everyone, were incorporated in the natural law code to substantiate the natural slavery of indigenous people. Here we find, I contend, the seeds of the visual regime that operates today by using optical instruments developed in the nineteenth century to discriminate and rule. As a matter of fact, this intervention emerged from the increase of use of facial recognition technologies on population management, specifically on European migration control. I reflect over the employment of optical lens from the early use of the camera by Europeans in colonial times in connection to contemporary facial recognition as a tracking tool to detect and encamp people on the move. I believe that this archaeological methodology with an aesthetic sensibility allows me to reveal how contemporary disciplinary techniques of image capture are held up by a complex relation of power and knowledge framed within the same biometric logic of truthseeking that marked the European colonial domination. "No matter how post one's once stance may be, the fact of living both colonial relations that are alive and well and postcolonial predicaments at the same time, should command our political work and analytical attention." (STOLER, 2016, p. ix). Thus, my engagement intends the postcolonial contribution capable of detecting how colonial inequalities endure today in a different form. There is no clear temporal cut in the post but a long present that morphologically adapts to different circumstances. As with the idea of the postcolonial, the role of visual technologies to monitor, survey, classify and eventually discipline target populations cannot be relegated to the past. This is very much the concern of scholars who want to critically engage contemporary biopolitical practice to scrutinize the mobilization of biometric technologies in a multitude of implications and scopes 
(not only images, but heartbeat, temperature, brain waves, eye scan, etc.). For marginality is first a way of seeing, whose force resides in its instability - the only thing that remains constant is the distance of the margins from the point of observation.

Since this article is about ways of seeing to a large extent, its focus - pun intended - is on power relations, embedded within these processes of visual depiction and assemblage. I do intend the later as a technology not only to describe, but also to disseminate those descriptions. Along these lines, I will proceed by briefly considering when the camera broke into the territory of the colonies and how it was instrumental not just to support colonial endeavors, but to perform that power by placing humans on a scale. Then I will attempt to show how today the lens is still a powerful technology that can, in a similar way, identify, classify, and neglect certain human beings across the European continent. Certainly, to consider facial recognition's risks entails a meditation over the concept of the archive which translates into contemporary databases. A somehow comprehensive, even if only superficial, account of the wide variety of aspects involving facial recognition should consider a critical review of machine learning models, the use and abuse of algorithms, and, in general, a reflection over the ethics of artificial intelligence (AI). This is simply too vast, and while I will certainly mention some significant texts of the contemporary expanding literature, this is beyond the scope of my intervention, whose emphasis, as I mentioned before, is to display the implications of the idea beneath Fanon and Markmann's (1967) corporeal schema in which he found himself locked. Thus, I am going to conclude my article by considering how a powerful contemporary artist repositions the colonial archive and problematizes today's racial coding through her technique of photomontage that rearranges together old photographs of racialized subjects and suggests new speculative directions.

\section{Colonial gaze}

We are mostly what we remember. Confronting the roots of our memory is an exercise of self-reflection that cannot be reduced to a simple rhetorical stunt. As Coates (2014) reminds us, historical crimes that go unaddressed generally reappear if only in other forms. Questioning the epistemology of European control techniques via an aesthetically-informed study, then, inevitably means to take measures with the idea of Europe as a byproduct of the European colonial gaze that, while sketching the profile of the European man, drew the line of "the colonial difference" (MIGNOLO, 2005). Photographs were not produced as records of colonial encounters but as a form of communication and a tool of domination. Teju Cole (2019) reminds us how the 
camera became immediately essential within European colonialism, together with the gun and the Bible, which pertain to the invention of the Man and the new order narrated in the opening quote by Wynter. It is relevant here to set these two elements and the hierarchy implied side by side with the colonial photographic archive. "The dominant power decided that everything had to be seen and cataloged, a task for which photography was perfectly suited. Under the giant umbrella of colonialism, nothing would be allowed to remain hidden from the imperial authorities." (COLE, 2019). Colonial images were intended to show back home colonized local populations as inferior but also exotic, docile but savage, inherently sub-human, because the colonies had to be part of the Empire but not too similar to the core of it. Together, erotic images of available young African girls half-naked and local warriors, finally tamed, framed in a submissive position, taken from a certain angle, were integral to the colonial endeavor and shaped racist views that reiterate the power relations behind those images.

Today a liberating wave is mounting around the globe ${ }^{1}$ questioning that gaze and the aesthetic order that derives from it. I mean nothing less than to question the narrative of modernity. For the first time in the European history, this wave of protest calls into question colonial statues in France but also in Italy and other countries, where, as place makers of European cities, those monuments were tasked to conglutinate the center to the limits of the colonial Empire (HENNEBERG, 2004). Given that political practice is always territorialized, the condition of foreignness was and is still projected into the national space by a constructed category, often based on gender and/or race. How so?

The $21^{\text {st }}$ century, with September 11 as its incipit, saw the tridimensional renovation of such controls in width and depth with the growing role of sophisticated biometric technologies of surveillance that deepened scrutiny at the skin level and beyond. Like with virus infections, controlling migrants' trajectories required coordinated and immediate response and the deployment of the latest technologies of surveillance and control at multiple levels. Today, drones armed with thermal-vision cameras, and facial recognition software can detect a heartbeat not only to detect migrants crossing borders at the geographical limits of the European Union, but within it, criminalizing and marginalizing individuals with certain somatic characteristic.

\footnotetext{
${ }^{1}$ We must credit the Black Lives Matter (BLM) movement in the USA, as much as elsewhere like in the Middle East, where there is a growing portion of the global Jew community that finds itself at odds with Israeli policies in the West Bank and Gaza.
} 
Here rests the central contradiction of modern European Renaissance humanism with the invention of the Man as a member of a specific ethnoclass and its overrepresentation (WYNTER, 2003). Within that, as Foucault (2003a) clearly demonstrated, universalism and the discriminatory function of anthropological differences are not incompatible. Hence, the margin is always unstable and ubiquitous (BALIBAR and HAHN, 2002), always oscillating between different definitions that before were religious, then anthropological, and today technological, but always positively political. For "[...] there are no margins, just ways of seeing or observing places and people as marginal." (FORGACS, 2014, p. 6). And along these lines, since the invention of the camera, the profiles of damnés of this world have always been in the spotlight. Today those silhouettes are captured by facial recognition technologies. Hypervisibility then, but also invisibility as their individuality, the complexity of their existence, the unicity of their being, has never been revealed to the point that to attain political subjectivity has been always awfully hard. Thus, the face has become a mask that does not protect, but that instead criminalizes and marginalizes. In here, photographic archives of the past and mugshots of the present, juxtapose.

\section{Across the fence of the Empire}

\section{How many ways can you clone an Empire? Dice a people, digit by digit?}

(PATEL, 2010, p. 5)

Within my area of expertise, which encompasses European politics of migration control, a truly comprehensive discussion cannot avoid facing the changes that technological advancement has brought into it, and asking what forces are implicated in this change. However, border practices intended only as governments' tools of control do not account for the application of technologies that are overproduced in highly industrialized societies of Europe and re-employed by African migrants. We should always acknowledge the circular dynamics of technological production together with the insurrectional role of human migrations as two distinct but complementary aspects of globalization. If we intend these forces in the form of a mutual constitutive grand narrative, eventually it will dislocate the illusion, but also the reasons behind a never-ending effort to set up a system of a total control. The aim, thus, should be to move on to delineating an ecology of human migrations that help us comprehend the spatial and temporal inter-relationships between migrants and the economic, social, and political structure of control. Nevertheless, this section is 
concerned with those who dwell on borders, as they risk everything to cross them, or live stuck on the steel curtain, "[...] chain-link fence crowned with barbed rolled wire" (ANZALDÚA. 2007), where security seldom stands for migrants' safety. Contemporary management of human mobility is conditioned in many ways by a concept of race that is bound to imperial colonialism in all its declinations of war, slavery, endured labor, and environmental degradation that define our world today. Hence, people traversing territories of the late colonial empire today are "cut digit by digit" (PATEL, 2010) by technologies of discrimination which were initially conceived and applied in the same domains.

Since the EU was awarded the Nobel peace prize in 2012, the militarization of its borders has been widening with a steady tempo in terms of depth and orbit, boosting the border and migration management budget for the 2021-27 interval. The human tragedy of Afghans and Syrians at the border between Poland and Belarus is only the last friction at the gates of Europe which is highlighting the contradictions and hypocrisy of European member states (POLAND ..., 2021). The EU recently launched a mechanism that "facilitates" the regional bloc's ability to stem unwanted migration by providing, for the first time ever, training and equipment and weapons to non-European forces (CAMPBELL, CHANDLER and JONES, 2021). The irony of its name is striking - European Peace Facility (EPF) (EU SETS UP..., 2021). To comprehend where the securitarian approach originated, we must go back in time precisely to June 14, 1985, when the Schengen treaty was signed initially only by five European member states. The document led most of the European countries towards the abolishment of their national borders. It was indeed aimed to build a Europe without borders, known as the "Schengen Area". But at what price? The external border became harder, internal checks became ubiquitous (BALIBAR and HAHN, 2002) and ultimately multiplied while the archive of control scaled up.

Back in in 1995, the Schengen Information System (SIS) was the first European database developed for migration control purposes. The reason for its introduction emerged ten years before, when the Schengen Treaty mentioned above was signed to eliminate internal borders of Europe and facilitate movement of labor guaranteed in the Treaty of Rome, along with free movements of goods, services, and capital. As I have suggested, the collapse of internal checkpoints as consequence of the Schengen Treaty required the registration of every good and person who was refused entry at the external checkpoints. Today the SIS has been updated and reinforced with new facial recognition technologies. As a matter of fact, "[...] given the reliability of 
identifying persons using fingerprints and photographs or facial images, they should always be inserted in alerts on return." (EUROPEAN PARLIAMENT, 2018, p. 11) Speed and traceability are the key elements behind the development of technologies of surveillance. It is not a coincidence that the development of SIS is strictly connected with the Schengen area of free movement and marks the beginning of a new era of European migration policy, characterized by the reinforcement of external borders. The information system was designed as a tool of inter-communication among different crossing points. With the entry of East European countries in the EU, SIS was expanded into SISII and SISone4all to cope with the increase of goods and people crossing the borders of Europe. At the end, SIS turned out to be the biggest European database. And in 2010, "[...] SIS contains over thirty-one million records, including more than one million records of persons" (EU, 2010).

Next to SIS, Eurodac was designed to deal with asylum requests according to the Dublin convention of 1991 that forbids multiple requests of asylum into different states, which has been cynically defined as 'asylum shopping'. The Eurodac database

Enables European Union (EU) countries to help identify asylum applicants and persons who have been apprehended in connection with an irregular crossing of an external border of the Union. By comparing fingerprints, EU countries can determine whether an asylum applicant or a foreign national found illegally present within an EU country has previously claimed asylum in another EU country or whether an asylum applicant entered the Union territory unlawfully. (EU, 2000).

Currently the EU relies on biometric data to record asylum seekers fingerprints, and, with the second generation of SIS, developed to register any entry into the Schengen Area, is equipped with biometric technology called Automated Fingerprint Identification System, whose results are then stored in the Biometric Matching System (BMS). Lastly, the Visa Information System (VIS) has been designed to record all visa applications of third nationals (non-EU) and will make use of the same technological infrastructure of SIS for storage, namely the BMS. To indicate the size and capability of VIS alone, according to the Home Affairs, "[...] the VIS database will become one of the largest biometric databases in the world, storing close to 70 million fingerprint sets after a period of five years and allowing accurate and rapid one-to-many searches." (BROM and BESTERS, 2010, p. 455).

More than ever, today speed appears to be the main objective of the latest European project to manage the circulation of people across the EU member states. 
The ultimate scope is to enable faster and thorough border control for third country nationals crossing the land borders of EU member states (MS), with technologies that adopt the schema of the Schengen Border Management. Along these lines, iBorderCtrl provides a unified solution with the aim of speeding up the border crossing at the EU external borders while at the same time enhancing the security and confidence regarding border control checks by bringing together many state-of-the art technologies (hardware and software) ranging from biometric verification, automated deception detection, document authentication and risk assessment. Roborder, as the name suggests, instead aims at developing and demonstrating an autonomous border surveillance system with unmanned mobile robots including aerial, water surface, underwater and ground vehicles which will incorporate multimodal sensors as part of an interoperable network. Its developers final goal was "[...] to implement a heterogenous robot system and enhance it with detection capabilities for early identification of criminal activities at border and coastal areas along with marine pollution events." (ROBORDER, 2020).

The future of unmanned operational vehicles to detect and visually capture people on the move is already here. Since last year, Frontex, the intergovernmental European agency on migration control, is operating unmanned drones for surveillance missions carrying electro-optical cameras, thermal imaging cameras and so-called 'daylight spotter' systems that independently detect moving targets and keep them in focus. Well-informed about the organic dimension that links technology to migration, other equipment includes systems for locating mobile and satellite telephones. Interestingly enough, the drones will also be able to receive signals from emergency call transmitters sewn into modern life jackets. However, the Frontex drones will not be used for sea rescue operations, but to improve capacities against unwanted migration. People will again be left to die, but somehow a machine will witness - not necessarily record - the human tragedy.

The ethical implications and reflections are many and go beyond the scope of this intervention. Still, I have discussed elsewhere (RINELLI, 2017) how the multiplication of control technologies did not increase the ability to rescue lives in distress at the margins of Europe. Quite the opposite. Those in need of help are abandoned to die in the desert as well as in the water, putting in motion a sort of camp effect around and within Europe. Take for instance those thousand Africans that recently were literally swimming through the moat (IN PICTURES..., 2021). 
Nevertheless, a thorough debate that encompasses the economic system in which we live, and technologies of visual capture would also have to consider the fate of Black, Latino, and Indigenous people, trapped in infinite cycles of poverty and violence within the USA inner cities and/or in the ubiquitous prison system of that country and beyond. One fundamental predicament of today's global relations is exactly the exacerbated tension between management of free trading, and human migration surveillance. It would be important to reflect on the tension originated within the contemporary neoliberal model of economic development that put in competition countries where the capitalist system of production is at very different stages of development, like the European Union and the Maghreb region, for example. Structurally, this gap produces, on the one hand, a rising unemployment of local working classes in countries of older industrialization, and, on the other, the proletarianization of the population in the South of the world. The vicious liminality of these uneven levels puts on the roads millions of men, women, and children who see themselves with no future, trapped in a situation of artificial stasis of their home country, because "[...] its essential stagnation denies life and resembles death" (BERGER, BLOMBERG, and MOHR, 2010, p. 36) - thus, they migrate. People leave because they want to live, even if they are perfectly aware that there is a risk of dying before they arrive in Europe, which is awfully soaring because of the securitization of the frontier, which gets reinforced as they move, in a vicious destructive cycle.

\section{Race and the Universal at the foundation of modern Europe}

Early European explorations can be set side by side with present postcolonial flows. Still, those quests are never discussed as a form of human migration but as heroic feats; however, like any other human migration, it shaped the world as we know it. Arguably, following Columbus' erroneous trajectory, the Man was born: a Christian white European male as the universal category to be applied to 'all' human beings. Its overrepresentation emerged and immediately flourished to the point that the two categories of the self and of the universal collapsed. The European man, by moving into the four corners of the Empire, became so pervasive that his image, projected over the whole world, cast out the rest of global population. He became the bearer of political rights while the Other was singled out as non-human, an irrational being, fundamentally unfamiliar to the divine realm, but also banned from the state. It was race and racism, then, the normalizing element of this exclusion. 


\begin{abstract}
What it was to be a Christian - to be, therefore, in their own conception, the only possible and universally applicable mode of being human, yet as a mode which nonconsciously carried over, as the referent of "normalcy," their own somatotype norm in the same way as their now purely secular and biocentric transformation of Christian, Man, overrepresented as if its referent were the human, now continues to do, even more totally so. (WYNTER, 2003, p. 303).
\end{abstract}

As we mentioned above, the individual collapsed and internalized the idea of the Man, and carried it over at the unconscious level. Consider the tragic event that occurred three years ago in Florence, Italy. It was the 5th of March, 2018. Roberto Pirrone, an ordinary man, 65 years old, leaves his house and walks through the mist of a city that is beginning the new day routine with the intention of taking his own life. But he could not gather the necessary strength; instead, he will later claim: "I decided to kill the first person I see." Not quite so. His path crossed past a family, then other people, but when he caught sight of Idy Diene, 54 years old, from Senegal, he had no hesitation. Idy was shot multiple times in his chest while crossing the river, and died on the spot. The public institutions promptly assured that they excluded any racist motivation, but the Senegalese community dissented and eventually clashed with the police, tired of being a target in a city that had witnessed already the most brutal racist assassination a few years before. It was in 2011 when two Senegalese vendors were shot dead in a public square market at midday.

There is an aesthetic connotation within the construction of race, in the way it has been naturalized and consolidated, that is inherent to it and operates also at the unconscious level. Reading about the tragic event of Diene's assassination, I could not help but relate that event to the main scene of The Stranger (CAMUS, 1988). The first part of the book ends on a sunny beach where Meursault shoots and kills an Arab. Like the novel's main character, Pirrone is not only at odds with the society around him, but also to himself, and he chose as his target the first person that, according to racist stereotypes, is perceived as a stranger. In 1957 Albert Camus won the Nobel prize because his opera calls our attention to the problems that are present every day in the conscience of men. One of these problems is related to the fact that we tend to avoid discussing the history of race and colonialism at the foundation of Europe, which in many ways accounts also for the fact of society glossing over any serious attempt to consider one's own identity. It is the comforting assumption of an eternal present that 
preserves a habitual numbness... until a stranger crosses our path revealing our own deception, lost and stuck between the lines of the archive.

\section{Canon, or the photographic archive}

The archive is first the law of what can be said, the system that governs the appearance of statements as unique events.

(FOUCAULT, 2003b, p. 145)

We recognize something which has been included in an archive when we have acknowledged it before. Since the first use of lens to capture the contour of specific human bodies, scholars have questioned and problematized concepts of consent, power relations and the whole content of the colonial photographic archive. Within it, the white man has been seldom a specimen. The large dataset of people's somatic traits has often been employed to single out targeted groups to exercise authority over individuals and eventually justify hostility when needed. Optical lens has been instrumental to classify certain individuals and to purify the body of the nation from undesirable elements, either external or already within its limits. Speaking of how race has been a crucial signifier for the shaping of the nation, Italo Calvino reminds us of how certain books become canon for the same nation. "They are books that exert a particular influence both when they impose themselves as unforgettable, and when they hide in the folds of memory, camouflaging themselves as a collective or individual unconscious." (CALVINO and ROSCIONI, 2017, p. 7). Take for instance the renowned work of the criminologist Cesare Lombroso, who in 1876 writes Criminal Man (LOMBROSO, 2013) to describe the backward reality of the Southern part of the new Italian state that, according to his analysis, was made up of deformed bodies and deviant behavior. Here, for example, is the portrait of a thief: small skull, receding forehead, mobile eyes, often gray-blue, thick and close eyebrows, marked nose, sparse beard and hair, protruding ears; short stature, slender and nervous figure, with chest and arms marked by tattoos and scars; not very muscular and therefore unsuitable for prolonged work; with low sensitivity and therefore capable of enduring torture of all kinds, just to mention same samples. Does it read familiar to the way white explorers described indigenous subjects?

The English scientist, Charles Darwin - of whom Lombroso read before many others the Italian translations of "On the Origin of Species" (1859) and "The Descent of Man" (1871) - and the Italian linguist concurred on a similar methodology that 
classifies living beings according to a scale that sees the primitives (the hieroglyphic writing as code) at one end, and the whites (the alphabetic writing as code) at the other. With this method of linear simplification, Lombroso is interested in the history (origin and evolution) and geography (variety) of populations. This is how Lombroso (2013) defines the "colored man" and, in particular, the one with the "gloomy" skin: curly and woolly hair, decidedly abundant; simian skeleton (mainly feet and hands); poorly developed and lightly heavy brain; poorly developed forehead; angled teeth; blood that clots quickly; peculiar smell; immune to yellow fever; precocious in development but only until puberty, when he becomes an adult but remaining in a childhood state. As for behavior, according to Lombroso (2013), blacks concentrate negative tendencies, including anthropophagy and prostitution (if a woman), becoming the primitive par excellence: superstitious and fetishist, insensitive to pain and emotionally unstable, he adorns the body with rings and tattoos, he is cruel to children, women, the elderly and the sick, loves wine more than family, defends the tribe with stone weapons, lives in caves or huts. To underline the immediate evidence of the description, Lombroso proposes some similarities of evolutionary origin: black is like a white child or like a backward adult. By reworking these images, Lombroso formulates his atavistic hypothesis in 1871 (reason why "The white man and the black man" [LOMBROSO and RODLER, 2012] is an important text): a certain type of man shows primitive somatic and behavioral characteristics that belong to a stage of development backward compared to the present one. A precise morphology of the populations is therefore important to define the degree of evolution: the measurements of the skull, according to the physiognomic and craniometric tradition (from Peter Camper to Franz Joseph Gall), those of the whole body, classified among others in the nineteenth century by the French anthropologist Paul Broca, who also numerically indexes skin color; and then the language (in the tradition of Giambattista Vico), the physical and moral sensitivity and behavior show the being in continuous transformation.

In the prisons it is common to find the Mongolian type with slanting eyes, the protruding cheekbone, the scarcity of the beard, the sucking forehead, the enormous frontal breasts, the yellow or earthy complexion of the Mongols [...] many alienated ones are made, at the onset or at the worsening of their sad infirmity, darker and even bronzy to the skin; and I saw cretins in our valleys who, at the length of the skull, the protrusion of the muzzle, the thickness of the lips and even the darkening of the skin, seemed badly whitened negroes. (LOMBROSO and RODLER, 2012, p. 171). 
Based on this experience, Lombroso develops the hypothesis of a link between atavism and delinquency. My interest in the text on races consists precisely in this: the belief that the physical anomaly in comparison with the "normalcy" of the Man brings men closer to what is savage and primitive, and that is the origin of deviant behavior. On the one hand, there is the "normal" man, that is, white, honest, hardworking; and on the opposite side of the human spectrum, there is darkness, represented by primitives, madmen, and later by criminals and prostitutes. This approach that links morphology and delinquency became so popular that, as mentioned by Calvino above, it became part of the national collective unconscious until today.

For a person to become a specimen and be classified in a certain group, a certain set of power relations must be in place in that society at a certain moment. A subject must be able to take the picture, and another to oversee the classification, while the audience for whom the photographic archive is intended rests quite distantly, both geographically and culturally, from the specimen, and thus automatically internalizes the power relations behind that image. The Atlanta shooting (VINOPAL, 2021) of last March 2021, which killed eight people, including six Asian women, is only the last episode of a long history of racist attacks and abuse against the Asian population in the US, based on a distorted communication whose ontological anchorage is to be found on those images of faces and bodies that fueled erotic fantasies of possession, control and colonization. Consider for instance this informative pamphlet (LIFE MAGAZINE'S..., 2007) from 1941, in the US, in which Life Magazine (Figure 1) "[...] adduces a rule-of-thumb from the anthropometric conformations that distinguish friendly Chinese from enemy alien Japs." The intended function here is officially to clarify and distinguish among two different Asian races to spare one - the Chinese - from the racist attacks that were quite common at that time, as the Japanese US citizens had been declared internal enemy. But in doing so, the pamphlet pinpoints physical features and freezes them visually to fit within the typological scheme of races. Still today observation and measurements of different points are central to technologies of facial recognition. 
Figure 1 - How to tell Japs from the Chinese
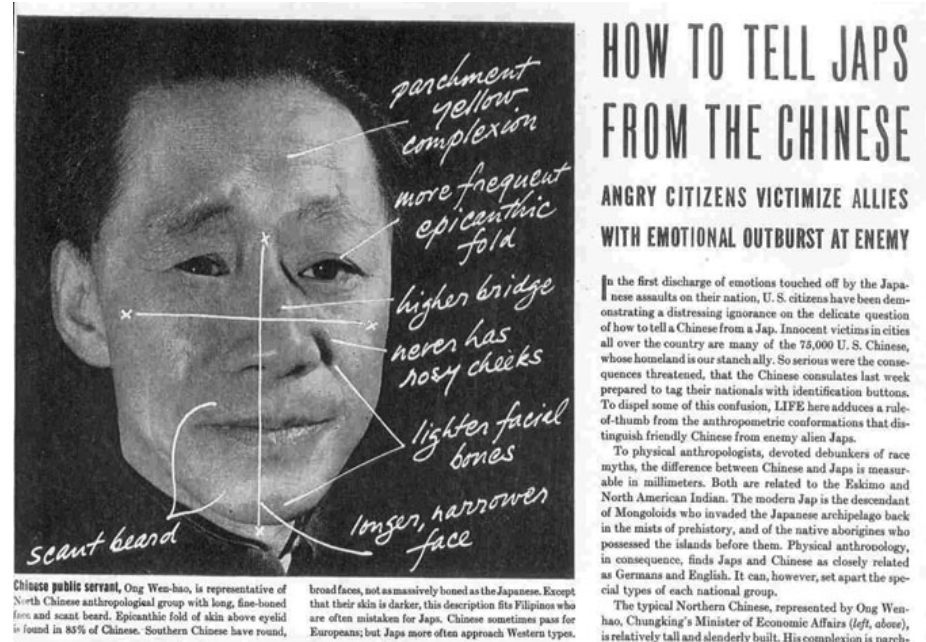

ANGRY CITIZENS VICTIMIZE ALLIES

WITH EMOTIONAL OUTBURST AT ENEMY

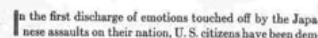

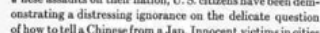

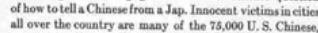

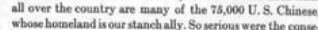

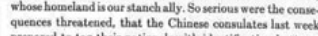

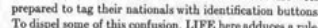

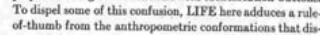

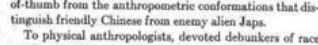

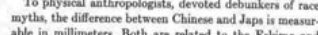

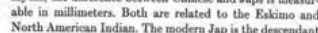

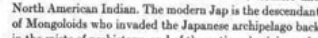

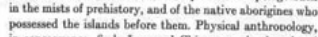

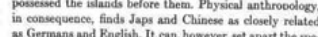

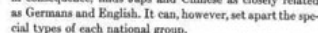
cial types of each national grovop

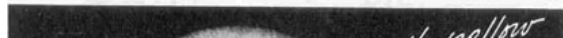

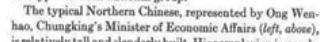

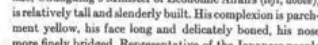

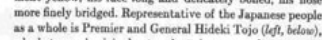

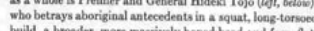

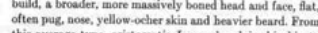

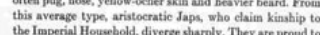

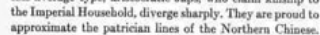
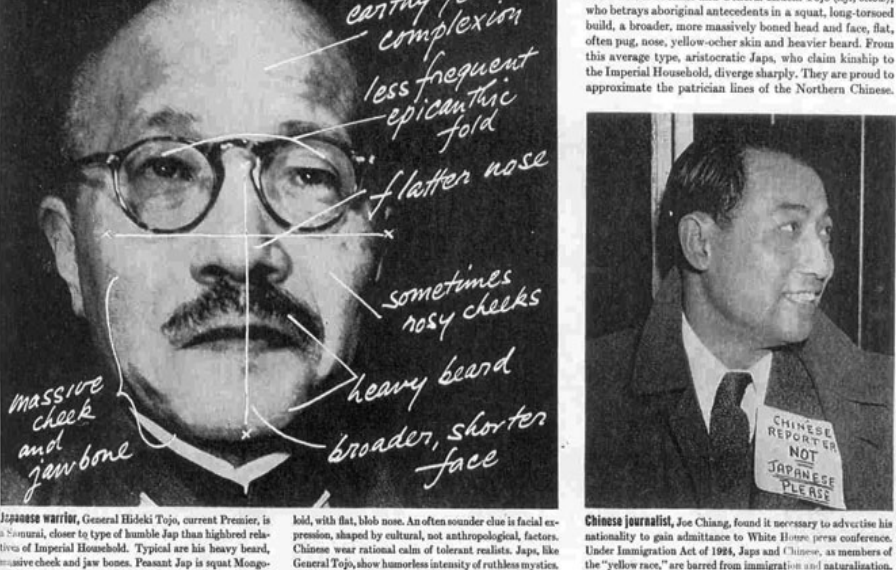

Source: Life Magazine's... (2007)

This is the clinical gaze as described by Foucault in the birth of the clinic (FOUCAULT 2003b). The new optical power of the European citizen/colonizer visualizes what the emerging criminal anthropology and forensic medicine were associated with: the capacity to individualize and classify abnormal individuals without judgements of value getting in the way of the facts. It is worth noting that the second half of the $19^{\text {th }}$ century is the time in which novels that take place in the underworld become increasingly popular (Mary Shelley's Frankestein or Bram Stoker's Dracula, 
just to mention two of the most notorious), and often the two disciplines - criminal anthropology and novel writing - merged, either because the latter aspires to be more scientific and credible, or because the former's authors aspire to arouse particular responses in the readers. Either way, the other becomes the deviant individual, always from or dwelling in the margins, often intended as the ghettos that were the result of the accelerated growth of post-Industrial Revolution cities. But also, the margins are colonies, intended as the appendix of European empires, as I mentioned above, at once extension of it but irremeably other, inviting, and repellent. Early colonial photography shaped this dichotomy. Distinctive archives with different focus were arranged and organized by each European power: thus, there were clinical, anthropological, sexual archives, and more often than not they had a military intent, either focusing on atrocities and torture or with a geographical focus - the land to be conquered and raped. In any case, they reveal specific power relations embedded within the process of visual depiction that remain the same today when dealing with people at the margins. Who owns and can point the camera? At whom? Who can look at those archives when compiled? For whom are those archives arranged?

\section{Acquisition of corporal data}

Vision requires instruments of vision; an optics is a politics of positioning. Instruments of vision mediate standpoints.

(HARAWAY, 1988, p. 193)

The body is a source of data. When it is featured, the face acquires a cultural intelligibility inscribed in a set of power imbalances. It is crucial then to comprehend how the body is translated and captured. Gilles Deleuze's Postscript on the Society of Control (1992) emerges as a highly influential piece in explaining the shift from a disciplinary society of the $19^{\text {th }}$ century, especially regarding millions on the move, embodied by Ellis Island, to a contemporary society of control. Deleuze claims that disciplinary societies are turning into control societies, from an analogical system to a digital one, where power has become more fluid, abandoning structures of confinement in favor of fluctuating networks where the lines (borders) are blurred and where the inside is not so distinct from the outside. Deleuze argues that "[...] whereas discipline set up a productive tension between masses and individuals, with control we witness a world of 'dividuals' whose context is not the mass or society, but proliferating databanks, profiles and markets" (RINELLI, 2016, p. 80). 
In this direction, Didier Bigo (2008), taking inspiration from Foucault's concept of disciplinary societies, develops the concept of 'Banopticon' to describe contemporary social practices of control, realized by the 'routinization of the monitoring of groups on the move through technologies of surveillance.' The French scholar sustains that border practices of surveillance appear here and there, outside and inside, as in a Moebius strip. Bigo explains what he calls the Banopticon and how it differs from Bentham's Panopticon reread by Foucault:

The latter supposes that everyone in a given society is equally submitted to surveillance and control that exists a physical proximity between watchers and the watched, as well as an awareness of being under scrutiny. The Banopticon on the contrary, deals with the notion of exception, and the difference between surveillance for all but control of only a few. (BIGO, 2008, p. 6).

I contend that, since the early use of optics, certain individuals were singled out using that technology and, thus, marginalized and excluded. What certainly has changed today, looking at those samples above, is the speed and ubiquity of the ban. The dystopia of diffuse control along the frontier as well as inside and outside it is made possible by the implementation of technologies of control and security. What appears to differ today is the simultaneity of border practice in singular places, and how the same technologies are equally utilized to assist necessities of war, health, and business together. Then it is reasonable to claim that the border functions as a filter; today the border, in its technological reconfiguration, is extremely permeable and mobile. Like a firewall, it differentiates between low and high speed, it fights viruses and freezes Trojan horses, but at the same time, it exists because of them. It materializes here and there. As a matter of fact, there are points of interceptions, convergences and crises that manifest themselves on the geographical territory and appear sometimes and somewhere, but whose trajectories are often dislocated from a tangible materiality. This is particularly true when we refer to the virtual gateways of Europe.

When accessed at any nodal point of the network, these technologies materialize a digital template that will disclose clandestine identities without corporeal presence of the subject. Along these lines, a multi-million-euro border control project was launched in Spain at the end of April 2013 that sees drones, satellites and aerostats deployed over the southern Mediterranean. It provided the EU “[...] with an operational and technical framework that increases situational awareness and improves 
the reaction capability of authorities surveying the external borders of the EU." (ABOUT CLOSEYE, c2013). The project of "[...] collaborative evaluation of border surveillance technologies in maritime environment by pre-operational validation of innovative solutions" was intended to reinforce the SIVE project (Sistema Integrado de Vigilancia Exterior, Integrated System for External Surveillance), which has been in operation since 2002. It made use of radar and surveillance cameras scattered throughout the coastline to scan incoming vessels and intercept them if they are suspicious. The addition of satellite imagery, aerostats, and drones such as the Camcopter S-100 significantly increased the powers of state authorities acting in the Mediterranean Sea.

It is clear then how biometric technologies and data collectors operate within a system of population management centered on the concepts of speed and mobility. It is not essential to arrest or to correct anymore. It is important to understand how the implementation of these technologies relies on the assumption that biometric technologies will eventually gain the (SAMPLE, 2019) absolute truth of what one person is. I contend that fundamentally the method of acquisition did not change in the last 200 years. It consists in three fundamental steps.

Figure 2 - Man with eyes closed

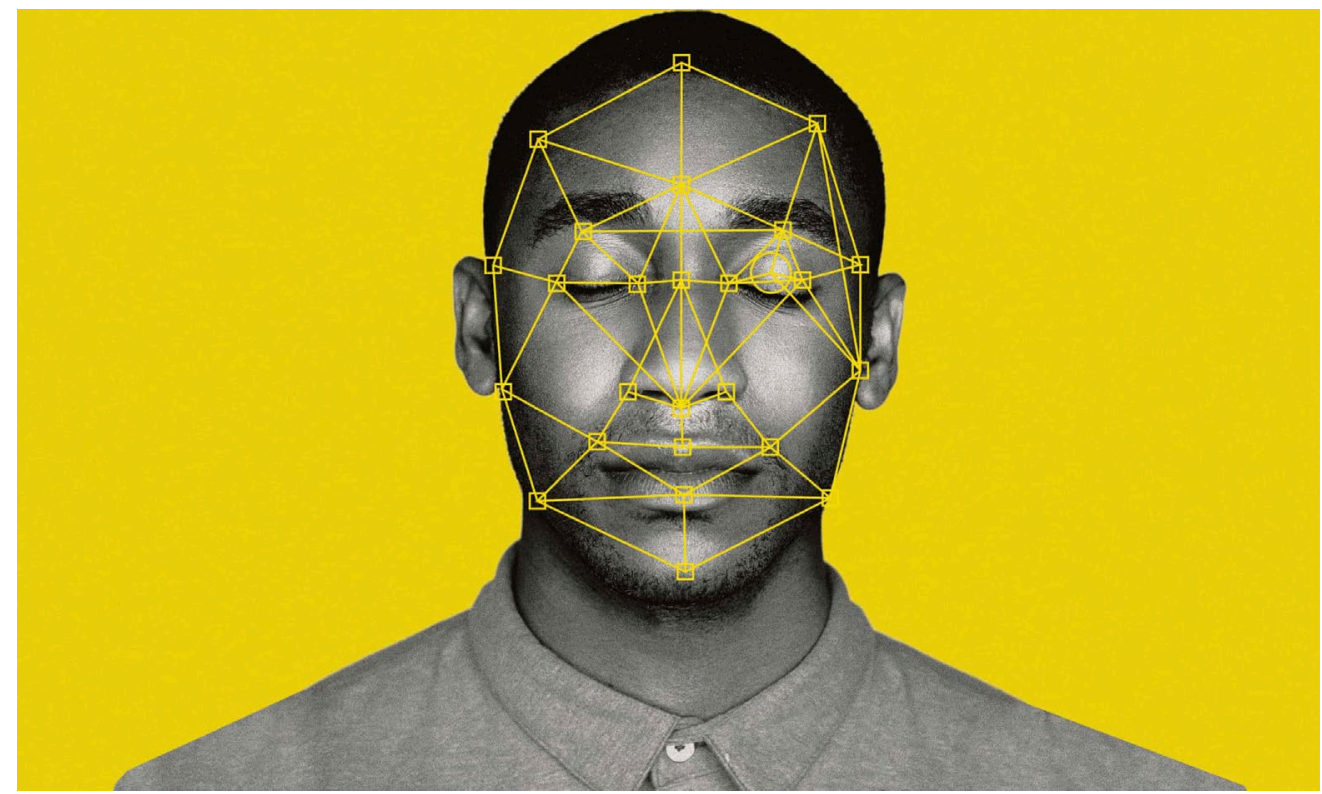

Source: Sample (2019). 
First, the body is presented in front of the camera. This may occur for different reasons. For instance, the subject may spontaneously put themself before the lens - this is the case when one needs access to secure locations or products, either financial or commercial. Differently, the person whose picture is taken is under the control of an authority in power and their image is recorded for the purpose of identification. An individual facial feature can also be acquired without the consent and awareness of the subjects, both in public and private spaces of contemporary cities - squares and shopping centers, for instance - where it is embedded in advertising hoardings to track the shoppers' age, gender and even mood, and that type of information has been deployed by police forces to scan for persons of interest. The legal implications of this misuse are many, and currently human rights organizations are challenging it at the European Court of Human Rights (COMPLAINTS..., 2020), also because of the inaccuracy of the images acquired. We will return to this aspect later.

In the case of coercive identification, it is worth noting how a similar approach has been commonly employed in the colonies for anthropological photos. As a matter of fact, the composition of early colonial portraits has been compared to that of police mugshot (HARGREAVES, HAMILTON, and NATIONAL PORTRAIT GALLERY, 2001), whose finality of security and identification is the main reason of facial recognition in general. Similarly, the subject is held in that position and the facial expression conveys that element. The background is neutral to give no clue to cultural and historical background of the subject, who is, thus, alien "[...] from all its spatiotemporal coordinates" (DELEUZE, 1986, p. 96), leaving to the authority in power the possibility to fill in and, thus, reinforcing the asymmetrical power relation between the viewer and the subject that is the ratio of this process of capture. The main difference between early colonial portraits and mugshots is that in the former the individual is nameless and unidentified as a specimen, to be catalogued and archived. It is important to underscore this aspect because, following Bigo above, the wide objective of contemporary facial recognition is to have everyone under control, but to put only specific individuals under strict surveillance. Even if general control is increasingly diffuse, it is not neutral or unbiased. In many ways, contemporary biases replicate/are based on the colonial set of power relations mentioned above: "The research literature increasingly acknowledges that algorithms are not neutral. The use of big data can thus lead to artificial intelligence to produce a disparate impact for minorities, women, and/or other traditionally disadvantaged group." (RHUE, 2018, p. 2). 
Once the automated lens captures the image of a face, it converts it into a template via an algorithm. There is a line of instructions that organizes how specific data will be analyzed and assembled, i.e., the distance between different points of the face. This process is based on the concept of ontology. The use of the term ontology in computer science derives from the previous use of the same term in philosophy, where it means the study of being and of becoming of the spirit that shapes entities entities subject to becoming. As in philosophy, ontology also describes entities that are subject to change according to the fundamental concepts of category and relationship. In other words, entities are not defined once and for all in an absolute way, that is, they are not metaphysical, but they attain value based on the relationships they can form with other entities. It is also the very concept of race as a "floating signifier" (HALL, 1996) that works in relation to other concepts and ideas.

The central point here is the similarity in relation to the mechanism of colonial photography exposed before. As I have emphasized in different passages above, for an image to be taken and to be put in conversation with others, a set of power relations must be in place between the person whose image has been captured, the authority who captures, the IT worker who oversees writing the instructions, and, finally, the audience who accesses it. When a group of researchers, two from the University of Washington and two from Google, published a paper (BENDER et al., 2021) that revealed the intrinsic flaws of the current machine-learning systems, including bias, gender, and ethnic discrimination, not to mention the enormous environmental cost of it, they caused a powerful wave of indignation around the world that caused the firing of Dr. Timnit Gebru and Dr. Margaret Mitchell (GOOGLE FIRES..., 2021). The problem centers around the relation between the data on a different number of faces from different groups of people. So, if a system is trained on a million white male faces, but just a few women and blacks, it will be less accurate for the latter groups. For instance, "[...] last year, the American Civil Liberties Union (ACLU) found that Amazon's Rekognition software wrongly identified 28 members of Congress as people who had previously been arrested. It disproportionately misidentified AfricanAmericans and Latinos." (SAMPLE, 2019). Less accuracy means more misidentifications and potentially more people being wrongly arrested and questioned, or/and excluded from financial opportunities. In a word: socio-economic marginalization. It resonates powerfully with the category of whiteness because white subjects, both the technicians and the subjects chosen as samples to train the machine, have positioned themselves somehow as transcending racial coding by colonizing the virtual territory like before, during colonial times, when referring to remote lands of 
the Empire. By occupying the positive pole of comparison, the white person in colonial photographs "[...] becomes an example of physical normality or harmonious design" (FORGACS, 2014, p. 98) and still today whiteness with facial recognition technology exceeds any racial categorization, but represents, again, the universal category against which the rest is measured. The Man is reborn.

This microphysical distribution of power relation is played out [...] and then proceed to store then within interoperative, multimodal and transnational electronic databases that connect, for example, the iris scan of an Iraqi citizen captured by the U.S: military to globalized systems of identification and surveillance. (PUGLIESE, 2012, p. 8).

We have engaged the concept of the archive before. Here it is enough to point out that the classification of people cannot transcend political relations, and, like in colonial times, classifications of the human species are always arbitrary. For instance, at a certain point, skin tone and height were considered not so relevant because those were elements that could change with migration over a few generations. Only the measurement of skull and skeleton mattered. Others instead claimed the opposite. Ethnic scales were created from the lowest darkest subject to the highest Semitic type with the white European Christian male. These categories were based on distinct regimes of representation that mobilized a certain way of thinking and acting toward those subjects, the damnés of Fanon, being migrant workers and/or inners cities minorities. In any case, the compilation of those categories reveals a complicity between the operator and the final user. The complicity essentially consists in a mutual agreement over the use of a known code. The term derives from the Latin verb cognoscere, that is, to have the knowledge of something or someone which we have experienced before. Every time a subject presents themself, voluntarily or by force, before the system, the machine is going to re-scan the facial details that must be recognized. We must always consider two aspects when reflecting over the act of capturing and framing the image of the black body based on the colonial gaze, both in the past and today: the aspect of hypervisibility and that of indistinctness. In a different historical context, the black face has been in focus, on the spotlight, but it has never been individualized. Colonial portraits have been the pivotal instruments of oppression that constructed and solidified ideas of race, crystallized in a hierarchical scale. "Some visual capture techniques fail to see Blackness while others render black people hyper visible." (BENJAMIN, 2019, p. 99). From the use of camera and image capture 
technology during colonial empires until today's apps of facial recognition, visual technology and racial classification reinforce each other, and that is "[...] the most efficient instrument of social domination invented in the last 500 years." (QUIJANO and ENNIS, 2000, p. 263).

What it is worth noting here is how contemporary technology of facial individuation has a poor response, especially when it comes to young black girls, with an error rate up to 34\% (KANTAYYA, 2020). And this happens while a growing portion of the global population, both within or exterior to the gates of the late Empire, had their image captured by a facial recognition technology and inserted into a network for financial/advertisement purposes and/or law enforcement. Having your image stored in such database is something like having your DNA or fingerprints in that database. It is worth noticing that Western state organizations, when it comes to those sensitive data, have built legal infrastructure to protect the privacy of citizens. However, to these days police forces can take everyone's biometric image in every advanced capitalist society because the citizen/consumer has been voluntarily handling a vast amount of data to giant companies. In the case of police enforcement, the legal gap will be eventually filled. On June 25, 2020, for instance, the United States Congress introduced a bill that prohibited the use of U.S. federal funds to acquire facial recognition systems or "any biometric surveillance system" (USA, 2020) used by federal government officials. Hence, Amazon and other technology companies have been under pressure from civil rights activists and their own workers to halt the sale of face-recognition systems to law enforcement agencies, and early in the summer of 2021 some of them have announced they would pause sales of their software.

However, I contend that it won't alter the power relations imbalance, because what is more problematic than inaccuracy is that the current implementation of these technologies involves significant racial bias that is inherent to the functioning of the optical machine operated by a colonial gaze. In other words, regardless of its accuracy (BUOLAMWINI, 2019), the software can be abused by turning it into a mass surveillance tool, even weaponizing it with legitimation operated by a discriminatory legal system against already marginalized communities and migrants. To mitigate the harm caused by contemporary face recognition technology, in 2018 the Safe Face Pledge was drafted "[...] as opportunity for organizations to make public commitments towards mitigating the abuse of facial analysis technology. This historic pledge prohibits lethal use of the technology, lawless police use, and required transparency in any government use." (SAFE FACE PLEDGE, 2018). Where authorities face no legal restrictions in the use of these technologies of visual capture, they may confront 
tangible and more mundane ways to resist those technologies. This is the case of Hong Hong's recent protests, where police and demonstrators have been wrestling for the past two years, turning their identity into the main weapon. On the one hand, police agents stopped wearing identification badges as the violence escalated, and some protesters began to expose officers' identities online. On the other hand, protesters cover their faces with gas masks or balaclavas as they fear to be singled out targets for arrest even months after the event occurred. But also, as in any respectable science fiction movie, protesters began to use laser pointers to cloud and deactivate facial recognition cameras. When one of the protester spray-painted CCTV cameras black in front of the Chinese government office, it showed a possible future scenario where people refuse and fight the abuse of this technology. Thenceforth, when we realized that not only our face can give our identity away, but it may determine our very fate, and the shape of our own identity, it is crucial to move beyond, and perhaps deeper than momentary diversion tactics. A deconstruction of the colonial visual code is needed in the originality of a gesture that stands out from criticism, from the rejection of that code, but also from the announcement of a new construction.

\section{Photocollage}

Like the bodiless heads you see sometimes in circus sideshows, it is as though I have been surrounded by mirrors of hard, distorting glass. When they approach me they see only my surroundings, themselves, or figments of their imagination - indeed, everything and anything except me. (ELLISON, 2016, p. 3).

Light and invisibility, two crucial aspects of the novel Invisible Man, are at the core of this essay, and with those come differentiation, hierarchy, and intelligibility. This is the canvas where the politics of race take form, or, in other words, they come to be visually articulated because, as I wanted to demonstrate, race combines the gaze and the screen. Therefore, I am going to conclude my intervention by putting emphasis on this canvas as a political space that is, of course, manipulative, as we extensively discussed above, but also malleable. I intended it as a space of mediation and contestation. To elucidate the possibilities for unsettling the visual misrepresentations of the black body, we must analyze the racist relations that underpin what is visual and political since the beginning. Famously, Deleuze and Guattari (1987) define 'faciality' as a mode of signification and subjectification peculiar to Europe. Painting was faciality's positive effect but 
[...] the head, even the human head, is not necessarily a face. The face is produced only when the head ceases to be a part of the body, where it ceases to be coded by the body, when it ceases to have a multidimensional polyvocal corporeal code-when the body, head in-cluded, has been decoded and has to be overcoded by something we shall call the Face. (DELEUZE and GUATTARI, 1987, p. 178).

That is why European racism was the negative outcome of the Christ-face, the face of the average ordinary European white man, because primitive people... they have no face. Being foreign to the divine, to be godless, is also to not be part of the story of the Man resembling God.

Contemporary art, I contend, has the potentiality to subvert this mechanism, first by highlighting the Other's influence in the construction of the European modernity. In the case of modern art, it is well known how Cubism has been influenced by the African sculpture, as in Picasso's Les Mademoiselles de Avignon. In Europe modern buildings, designs and icons were permeated by African symbolism that became a sign of outward-looking and advancement against old racist visions. But it lasted for a decade or so, and later racist visions colonized again the visual space until today. More fundamentally, artists unleash creative lines of flight which escape the constraints of representation, which is not an image, but a machine, a techné. "And isn't the art [techne] naturally directed toward seeking and providing for the advantage of each? Yes, that is what it is directed toward." (PLATO, 1974 [341d.]). It is then directed towards the creation of unseen features of her face, which is the locus of expression and communication.

Along these lines, I consider the ways in which contemporary artist Rujunko Pugh disturbs the colonial visual archives at its foundations and, thus, the contemporary racial ramifications that pervade today's techniques of visual capture. Inspired by the work of theorists such as Kobena Mercer, Stuart Hall, and linguist Mikhail Bakhtin, but also through the work of artists such as Romare Bearden, Firelei Báez, and Swoon, she impressively demonstrates how concepts of classification are never fixed through places and times, nonetheless they generate meaning. However, they are never essential; they can be reappropriated, always subject to renegotiation and redefinition. It is quite evident, above all, the influence of Romare Bearden, as she uses interruptive practices of collage with a cut-and-mix style, and thus, intends the screen of representation malleable and open to remaking. As Hall (1996) puts it: 
To the losing of old meanings, and the appropriation and collection on contracting new ones, to the endless process of being constantly re-signified, made to mean something different in different cultures, in different historical formations, at different moments of time.

In other words, with her photocollage Rujunko Pugh opens new temporal directions by recontextualizing signifiers of memory that were supposed to be shut, fading the vision of the contemporary racial archive. While facilitating alternative ways of seeing both histories and geographies, she is suggesting us new meanings within past and present contexts. But more importantly, she is stating how she exists for her art. This is what she does because this is who she is, and she says that:

By Mercer's criteria, I could be identified as part of the black diaspora; however, I apply Hall's description of identity as 'a matter of becoming as well as of being'. I will be informed by, but set aside, the ambiguous label of Asian/African-American and refer to my cultural identity as part of the Japanese/black diaspora from this point forward. (PUGH, 2017a, p. 31).

There is no separation between I do and I am in her work, and this element should not be minimized.

Following her statement, I consider here one of my favorite pieces of her opera, titled 19th Century Modern, which consists of twenty gel medium transfers in a fiveby-four arrangement referencing the modernist grid to acknowledge the influential role of Modernism in art history. She accomplishes it by acknowledging the social, geographical, and historical implications of it, by being attentive to time, space, and feelings in her creations. She makes use of the critical photomontage methodology, which opens space for reflection, giving new life and meanings to the women of the past who belonged to different archives and, thus, to different landscapes, cultures, and social histories. Her work, in other words, recombining signifiers of memory, questions contemporary classifications of race by making sense of the architecture behind contemporary devises of visual capture, revealing their implicit racial hierarchies. Regarding the creation of 19th Century Modern Transfer, photocopy transfer \#15, she clarifies that:

The base of the image is of a black Victorian woman, a person of the black diaspora assimilating the colonialist clothing and hairstyle from that period. Collaged into the base photograph is a part of a Japanese woman's 
face that always includes the eyes, an identifying feature of the Asian phenotype that has been sectioned from a Japanese albumen print. And the final component is a decorative element sourced from katagami stencil originally used for Meiji Era textiles. (PUGH, 2017a, p. 45).

Figure 3 - 19th Century Modern Transfer, photocopy transfer \#15

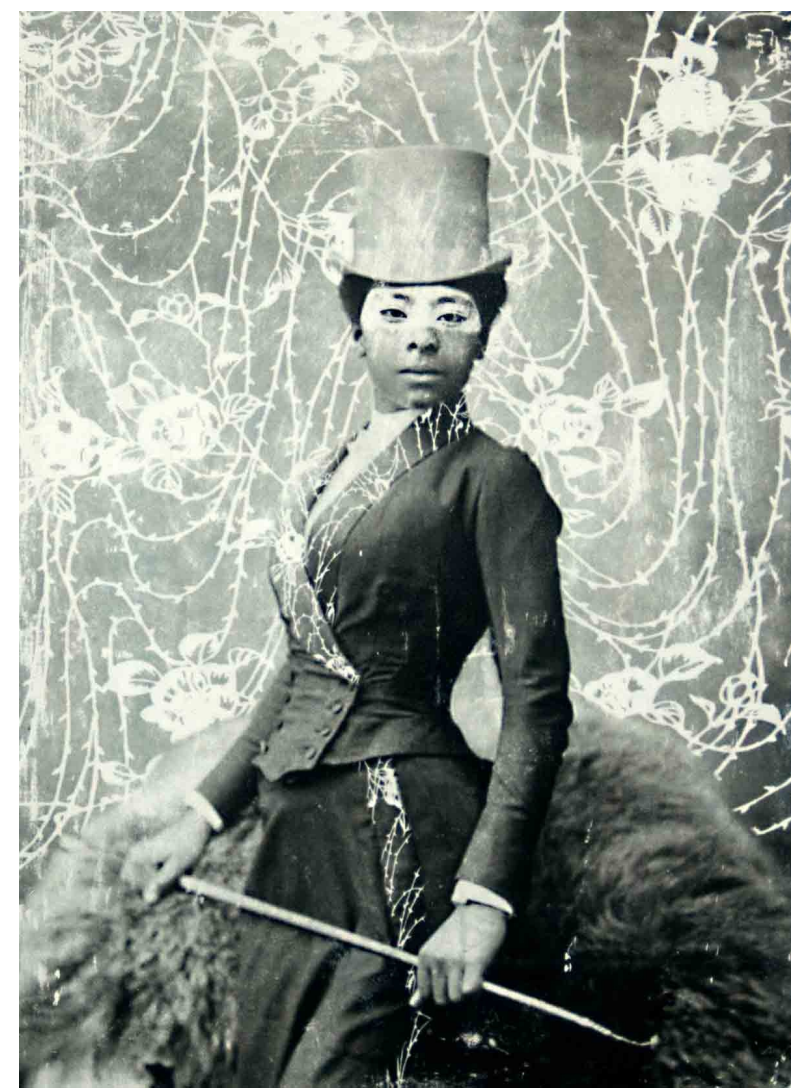

Source: Pugh (2017b).

\section{Conclusion}

Ann Laura Stoler (2009) considers the colonial archives as a process which reveals the stories that are rendered invisible but that are somehow not erased. In a similar way, as I have discussed above, the architecture of contemporary visual technologies works today with algorithms and cameras. The question is: how can formerly colonized and racialized subjects pierce the visual archive not as passive spectators or mere objects but as active participants? Rujunko Pugh's opera sheds some light on the scenery as she attempts to modify and signify the image repertoires which 
have been colonially constituted. In her creations, those suspended lives meet and resurface, inviting the viewer to discover points of contact between different histories and geographies. In a way, she invites the viewer to participate in feelings elicited by those marginalized and racialized subjects of the archive, demonstrating that those are historical waves that reverberate on contemporary screens. She is liberating those feelings that the colonial architecture intended to silence, and in doing so, the viewer attends to a moment of uneasiness that sparks attention and reconsideration. While doing so, she ultimately questions the alleged objectivity of the science behind the visual capture that since colonial modalities and the creation of the Man, had the pretension to authenticate its own biases - a predisposition that is possible to find at the core of facial recognition technologies all the more today.

Lorenzo Rinelli é Professor na Temple University Rome. E-mail: lorenzo.rinelli@temple.edu.

\section{Referências}

ABOUT CLOSEYE. c2013. Available at: <http://www.closeye.eu/>. Accessed July 6, 2021.

ANZALDÚA, Gloria. Borderlands/La Frontera: the new mestiza. $3^{\text {rd }}$. ed. Aunt Lute Books, 2007.

BALIBAR, Etienne; HAHN, Daniel. Politics and the other scene. Verso, 2002.

BENDER, Emily M. et al. On the dangers of stochastic parrots: can language models be too big? In: ACM CONFERENCE ON FAIRNESS, ACCOUNTABILITY, AND TRANSPARENCY, 2021, New York, NY. Proceedings of the 2021 ACM Conference on Fairness, Accountability, and Transparency. New York, NY, 2021. p. 610-623. doi: 10.1145/3442188.3445922

BENJAMIN, Ruha. Race after technology: abolitionist tools for the New Jim Code. Medford, MA: Polity, 2019.

BERGER, John; BLOMBERG, Sven; MOHR, Jean. A seventh man. London; New York: Verso Books, 2010.

BIGO, Didier. Globalized (in)security: the field and the ban-opticon. In: BIGO, Didier; TSOUKALA, Anastassia. Terror, insecurity and liberty. Routledge, 2008. doi: 10.4324/9780203926765-7

BROM, Frans W. A.; BESTERS, Michiel. 'Greedy' information technology: the digitalization of the European migration policy. European Journal of Migration and Law, v. 12, n. 4, p. 455-470, 2010. doi: $10.1163 / 157181610 \times 535782$ 
BUOLAMWINI, Joy. Response: racial and gender bias in Amazon Rekognition - commercial AI system for analyzing faces. April 24, 2019. Available at: $<$ https://medium.com/@Joy.Buolamwini/response-racial-and-gender-bias-in-amazon-rekognitioncommercial-ai-system-for-analyzing-faces-a289222eeced>. Accessed: Nov 24, 2021.

CALVINO, Italo; ROSCIONI, G. Carlo. Perché leggere i classici. New York: Knopf, 2017.

CAMPBELL, Zach; CHANDLER, Caitlin; JONES, Chris. Hard power: Europe's military drift causes alarm. The Guardian, May 19, 2021. Available at: <http://www.theguardian.com/world/2021/may/19/hard-power-europes-military-drift-causes-alarm>. Accessed: Nov. 29, 2021.

CAMUS, Albert. The stranger. Rev. ed. New York: Knopf, 1988.

COATES, Ta-Nehisi. The case for reparations. The Atlantic, June 2014. Available at: <https://www.theatlantic.com/magazine/archive/2014/06/the-case-for-reparations/361631/>.

Accessed: Nov. 24, 2021.

COLE, Teju. When the camera was a weapon of imperialism. (And when it still is.). The New York Times, Feb. 6, 2019. Available at: <https://www.nytimes.com/2019/02/06/magazine/when-thecamera-was-a-weapon-of-imperialism-and-when-it-still-is.html>. Accessed: Nov. 24, 2021.

COMPLAINTS filed to Human Rights Court over Moscow's facial recognition. IAPP, July 8, 2020. Available at: <https://iapp.org/news/a/complaints-filed-to-eu-court-over-moscows-facial-recognition/>. Accessed: Nov. 24, 2021.

DELEUZE, Gilles. Postscript on the Societies of Control. The MIT Press, v. 59, p. 3-7, 1992.

DELEUZE, Gilles. Cinema 1: the movement-image. Minneapolis: University of Minnesota Press, 1986.

DELEUZE, Gilles; GUATTARI, Félix. A thousand plateaus. University of Minnesota Press, 1987.

ELLISON, Ralph. Invisible man. Penguin UK, 2016.

EUROPEAN PARLIAMENT. Regulation (EU) 2018/1860 on the use of the Schengen Information System for the return of illegally staying third-country nationals. European Union, Dec. 7, 2018. Available at: <https://www.europeansources.info/record/regulation-eu-2018-1860-on-the-use-of-theschengen-information-system-for-the-return-of-illegally-staying-third-country-nationals/>. Accessed: May 24, 2021.

EUROPEAN UNION (EU). Council Regulation (EC) No. 6162/2010. Schengen Information System database statistics dd. 01/01/2010. Brussels, 2010.

EUROPEAN UNION (EU). Council Regulation (EC) No 2725/2000 of 11 December 2000 Concerning the Establishment of "Eurodac" for the Comparison of Fingerprints for the Effective Application of the Dublin Convention. 2000. Available at: <http://data.europa.eu/eli/reg/2000/2725/oj/eng.>. Accessed: Nov. 24, 2021.

EU SETS UP the European Peace Facility. Portal of the European Council, 22 mar. 2021. Available at: <https://www.consilium.europa.eu/en/press/press-releases/2021/03/22/eu-sets-up-the-europeanpeace-facility/>. Accessed: May 23, 2021

FANON, Frantz; MARKMANN, Charles Lam. Black Skin, White Masks. 1967.

FORGACS, David. Italy's margins: social exclusion and nation formation since 1861. Cambridge; United Kingdom: Cambridge University Press, 2014.

FOUCAULT, Michel. Abnormal: Lectures at the College De France 1974-75. 2003a 
FOUCAULT, Michel. The birth of the clinic: an archaeology of medical perception. Psychology Press, 2003b.

GOOGLE FIRES Margaret Mitchell, another top researcher on its AI ethics team. The Guardian, February 20, 2021. Available at: <http://www.theguardian.com/technology/2021/feb/19/google-firesmargaret-mitchell-ai-ethics-team>. Accessed: Nov. 29, 2021.

HALL, Stuart. Race the floating signifier. Goldsmiths College, 1996. (ca $71 \mathrm{~min} .57$ s). Available at: $<$ https://www.youtube.com/watch?v=PodKki9g2Pw>. Accessed Nov. 29, 2021.

HARAWAY, Donna. Situated knowledges: the science question in feminism and the privilege of partial perspective. Feminist Studies, v. 14, n. 3, p. 575-599, 1988. doi: 10.2307/3178066.

HARGREAVES, Roger; HAMILTON, Peter; NATIONAL PORTRAIT GALLERY. Beautiful and the damned: the creation of identity in nineteenth-century photography. Burlington, VT: Lund Humphries Pub Ltd, 2001.

HENNEBERG, Krystyna von. Monuments, public space, and the memory of empire in modern Italy. History and Memory, v. 16, n. 1, p. 37-85, 2004. doi: 10.2979/his.2004.16.1.37

IN PICTURES: some 8,000 migrants reach Spain's Ceuta from Morocco. Trtworld, May 19, 2021. Available at: <https://www.trtworld.com/europe/in-pictures-some-8-000-migrants-reach-spain-s-ceutafrom-morocco-46830>. Accessed: Nov. 29, 2021.

KANTAYYA, Shalini. Coded bias: TUL Streaming Video. 7th Empire Media, 2020.

LIFE MAGAZINE'S 1941 article 'How to tell Japs from the Chinese.' August 7, 2007. Available at: <https://anthropology.net/2007/08/06/life-magazines-1941-article-how-to-tell-japs-from-thechinese/>. Accessed Nov. 29, 2021.

LOMBROSO, Cesare. L'uomo delinquente. Milano: Bompiani, 2013.

LOMBROSO, Cesare; RODLER, Lucia. L'uomo bianco e l'uomo di colore. Letture sull'origine e la varietà delle razze umane. Bologna: Archetipo Libri, 2012.

MIGNOLO, Walter D. Prophets facing sidewise: the geopolitics of knowledge and the colonial difference. Social Epistemology, v. 19, n. 1, p. 111-127, 2005. doi: 10.1080/02691720500084325

PATEL, Shailja. Migritude. New York: Kaya Press, 2010.

PLATO. Plato's Republic. Indianapolis, Ind.: Hackett Publishing Company, 1974 [341d].

POLAND says Belarus still bringing migrants to its border. Aljazeera, Nov. 21, 2021. Available at: $<$ https://www.aljazeera.com/news/2021/11/21/poland-says-belarus-still-bringing-migrants-to-itsborder>. Accessed: Nov. 22, 2021.

PUGH, Keiko Rujunko. Cut and mix culture: visual explorations of contemporary diaspora identity. Sydney: University of Sydney, 2017a.

PUGH, Rujunko. Transference. 2017b. Available at: <http://rujunkopugh.com/Transference>. Accessed: Nov. 30, 2021.

PUGLIESE, Joseph. Biometrics. New York London: Routledge, 2012.

QUIJANO, Anibal; ENNIS, Michael. Coloniality of power, Eurocentrism, and Latin America. Nepantla: Views from South, v. 1, n. 3, p. 533-580, 2000.

RHUE, Lauren. Racial influence on automated perceptions of emotions. SSRN, Nov. 9, 2018. doi: 10.2139/ssrn.3281765

RINELLI, Lorenzo. Anglers of men: the politics of rescuing African migrants in the Mediterranean Basin. Review of Human Rights, v. 3, n. 1, p. 27-42, 2017. doi: 10.35994/rhr.v3i1.81. 
RINELLI, Lorenzo. African migrants and Europe: managing the ultimate frontier. Abingdon, Oxon; New York: Routledge, 2016.

ROBORDER. 2020. Available at: <https://roborder.eu/>. Accessed: July 8, 2021.

SAFE FACE PLEDGE. 2018. Available at: <https://www.safefacepledge.org/>. Accessed: Nov. 29, 2021.

SAMPLE, Ian. What is facial recognition - and how sinister is it? The Guardian, July 29, 2019. Available at: <http://www.theguardian.com/technology/2019/jul/29/what-is-facial-recognition-andhow-sinister-is-it>. Accessed: Nov. 29, 2021.

STOLER, Ann Laura. Duress: imperial durabilities in our times. Durham: Duke University Press, 2016.

STOLER, Ann Laura. Along the archival grain: epistemic anxieties and colonial common sense. Princeton University Press, 2009.

UNITED STATES OF AMERICA (USA). Senate. Facial recognition and biometric technology moratorium Act. MDM20746. Washington, DC, 2020. Available at: $<$ https://drive.google.com/file/d/1gkTcjFtieMQdsQ01dmDa49B6HY9ZyKr8/view>. Accessed: Nov. 29, 2021.

VINOPAL, Courtney. What we know about the Atlanta Spa shootings that killed 8, including 6 Asian women. PBS News Hour, Mar. 17, 2021. Available at: <https:/www.pbs.org/newshour/nation/whatwe-know-about-the-atlanta-spa-shootings-that-killed-8-including-6-asian-women>. Accessed: Nov. 29, 2021.

WYNTER, Sylvia. Unsettling the coloniality of being/power/truth/freedom: towards the human, after man, its overrepresentation -- an argument. CR: The New Centennial Review, v. 3, n. 3, p. 257-337, 2003. doi: $10.1353 /$ ncr.2004.0015

Texto recebido em 28 de outubro de 2021. Aprovado em 02 de dezembro de 2021. 